JOANNA NIECZUJA-DWOJACKA ${ }^{1 \star}$

JOANNA GRZELAK

ANNA SINIARSKA

KAMILA CHWAŚCIŃSKA

\title{
Sprawność fizyczna warszawskiej młodzieży gimnazjalnej
}

\section{Summary \\ Physical activity of Warsaw youth}

The aim of project was to estimate relationship between physical activity, socio-economic conditions and BMI in sample of youth. A group consisted of 177 youth aged 14-16 years from two Warsaw junior high schools. The research included questionnaire information (socio-economic condition, lifestyle), measurements and tests of strength, agility, endurance, flexibility, and reaction time. To determinate the relationship between fitness and five factors stepwise multiple regression was used. The results showed that higher stress level had negative influence on grip strength of hand and agility of shuttle run. Exposure to smoking had a negative impact on result in grip strength of hand, endurance, and explosive power of the lower extremities. The number of people in family had negative effect on grip strength of hand, however lifestyle had a positive influence on number of sit-ups (abdominal muscular strength and endurance). In case of youth characterized by lower BMI category, weaker handgrip and increased spine flexibility were observed. Socio-economic conditions mentioned above had small influence on physical activity.

1 Wydział Biologii i Nauk o Środowisku, Uniwersytet Kardynała Stefana Wyszyńskiego, ul.Wóycickiego 1/3, 01-938 Warszawa, *e-mail: j.nieczuja@uksw.edu.pl 
Słowa kluczowe: sprawność fizyczna, warunki bytowe, BMI Key words: physical activity, socioeconomic conditions, BMI

\section{Wstęp}

Sprawność fizyczną można określić jako umiejętność zrealizowania własnego potencjału ruchowego (Przewęda, Dobosz 2003). Jest to cecha zależna od wielu czynników, między innymi od genotypu (Garatachea, Lucia 2013: 90-102), w tym płci, oraz innych cech zależnych w dużej mierze od genów: wydolności, budowy i proporcji ciała, a także treningu i stylu życia (Huang, Malina 2002: 11-19). Motoryka człowieka zmienia się również wraz z wiekiem, od 4 miesiąca życia niemowlę zaczyna siadać, a od 12-13 miesiąca życia również chodzić. Od tego momentu następuje rozwój koordynacji ruchowej, która w wieku 4-5 lat osiąga relatywnie wysoki poziom i okres ten nazywany jest „złotym wiekiem motoryczności” (Wolański 2012). W wieku 12-13 lat młodzież jest zdolna przyswajać skomplikowane układy ruchowe, natomiast w wieku 12-14 lat wchodzi w etap dojrzewania płciowego, który może powodować zmiany w sprawności fizycznej, czy nawet regres niektórych czynności ruchowych. Związane jest to z działaniem hormonów, które przyczyniają się do modyfikacji proporcji ciała, np. wydłużanie kończyn dolnych i zmiany BMI (Osiński 2003, Huang, Malina 2010: 404-411). Wyniki badań ostatniego dziesięciolecia wskazują, że młodzież posiadająca nadmierne otłuszczenie oraz wysokie wielkości BMI charakteryzuje się niższym poziomem sprawności fizycznej (Januszewicz, Sygit 2003: 421-425, Szymura, Cempla 2003: 271-276, Huang, Malina 2007: 701-708, Gulías-González et al. 2013: 727-735), w tym gorszymi wynikami w testach wydolnościowych (Pälve et al. 2014, Radovanović et al. 2014: 204-209). Wśród czynników wpływających na sprawność fizyczną wymienia się także warunki bytowe, $\mathrm{w}$ tym poziom stresu, wielkość rodziny oraz postawę rodziców i opiekunów wobec zajęć sportowych (Osiński 2003, Gołąb et al. 2005: 66-70). Wielu badaczy podkreśla jednakże, że poziom sprawności motorycznej i aktywności fizycznej w ostatnich latach wyraźnie spada, a za przyczynę tego zjawiska uważa się szybki rozwój 
cywilizacyjny (Chabros et al. 2008: 99-102). Dzieci i młodzież chętniej spędzają czas przed komputerem i telewizorem niż na uprawianiu sportu (Jodkowska et al. 2007: 149-156, Wojtyła et al. 2011: 335-342, Rauner et al. 2013: 1-9).

\section{Cel pracy i hipotezy badawcze}

Celem pracy jest ocena zależności sprawności fizycznej młodzieży od warunków społeczno-bytowych i masywności budowy ciała (BMI). Oczekujemy, że większa sprawność fizyczna będzie cechowała młodzież posiadającą lepsze warunki bytowe, pochodzącą z mniejszych rodzin i mniej narażoną na stres i używki. Także młodzież, którą cechuje większy wskaźnik BMI może wykazywać gorsze wyniki w zastosowanych testach sprawnościowych.

\section{Materiał i metody}

Materiał pracy stanowiły wyniki pomiarów antropometrycznych oraz prób sprawnościowych przeprowadzonych na 177 osobach: 89 chłopcach i 88 dziewczętach w wieku 14-16 lat z dwóch warszawskich szkół na Bielanach: Gimnazjum Publicznego nr 73 i Gimnazjum Publicznego nr 74.

Status społeczno-ekonomiczny badanej młodzieży należy ocenić jako dobry. Większość rodziców posiada wykształcenie średnie i wyższe (odpowiednio 35\%, 39\% w przypadku ojców i 40, 43\% w przypadku matek). Także większość wykonywanych zawodów przez rodziców badanych to pracownicy wykwalifikowani i specjaliści (odpowiednio $50 \%$ i $29 \%$ w przypadku ojców i $24 \%$ i $32 \%$ w przypadku matek).

Badania składały się z części ankietowej i pomiarowej. Uczniowie, których rodzice wyrazili zgodę na badania, odpowiadali na pytania zawarte w ankiecie. Do charakterystyk warunków społeczno-bytowych zaliczono: liczbę osób w rodzinie, liczbę rodzeństwa, wykształcenie ojca i matki, zawód ojca i matki, liczbę pokoi, stres w domu i stres w szkole oceniany przez uczniów (niski, średni, wysoki), ocenę własną aktywności fizycznej (niska, średnia, wysoka), liczbę 
dziennych posiłków, palenie papierosów przez rodziców w obecności badanego (tak, nie).

Pomiary antropologiczne zostały przeprowadzone zgodnie z powszechnie przyjętymi technikami (Martin, Saller 1957, Malinowski 1980, Malinowski, Strzałko 1985, Malinowski, Wolański 1988, Malinowski, Bożiłow 1997) i były to: wysokość ciała oraz masa ciała (określana za pomocą wagi lekarskiej, z dokładnością do 100g). Na tej podstawie obliczono wskaźnik masywności (BMI: masa ciała w kg/ wysokość ciała $\mathrm{w}^{2}{ }^{2}$ ). Oceny sprawności motorycznej dokonano na podstawie testów opisanych przez Wolańskiego, Parizkovą (1976), Malinowskiego, Wolańskiego (1988) oraz testu Eurofit (Dobosz 2012):

1. Siła statyczna ręki dominującej, mierzona za pomocą dynamometru, wynik podawano w kg;

2. Zwinność określona za pomocą testu biegu po „ósemce”;

3. Wytrzymałość ustalona na podstawie liczby siadów $\mathrm{z}$ leżenia w jednostce czasu (próba Eurofit);

4. Gibkość kręgosłupa badana za pomocą przyrządu Groszenkowa-Wolańskiego. Mierzono długość kręgosłupa w cm w wyproście (DKW) i w skłonie (DKS) (w punktach cervicale lumbale). Wskaźnik gibkości kręgosłupa (WGK) to [(DKS $\mathrm{DKW}) / \mathrm{DKW}]{ }^{\star} 100$;

5. Siła eksplozywna kończyn dolnych. Badany stał bokiem z wyciągniętą ku górze ręką przy zawieszonej na ścianie desce z odpowiednią skalą. Mierzono wysokość dosiężną (WD) i wysokość doskoczną (WS) w cm. Obliczony wskaźnik Sargenta to $[(\mathrm{WS}-\mathrm{WD}) / \mathrm{WD}]^{\star} 100$;

6. Szybkość reakcji została wyznaczona przy użyciu linijki Quickstick o 10 stopniowej skali. Średnią uzyskano z 6 prób.

Dokonano przejścia rzeczywistych wyników wszystkich pomiarów i wskaźników na skalę „z”, która pozwoliła unormować wielkość każdej cechy badanego na średnią i odchylenie dla całego materiału, odpowiednio dla każdej płci i klasy wieku. Dokonano tego wg wzoru: $\mathrm{z}$ = wielkość cechy badanego - średnia danej cechy w zależności 
od wieku i płci / odchylenie standardowe. Przejście to umożliwiło porównywanie wyników badań bez podziału na płeć i grupy wieku.

Analiza głównych składowych pozwoliła na redukcję charakterystyk społeczno-bytowych od określonej liczby czynników. Za pomocą analizy regresji liniowej w wersji krokowej, gdzie zmiennymi niezależnymi były uzyskane czynniki, a zmiennymi zależnymi próby sprawnościowe, oszacowano zależność warunków społeczno-bytowych ze sprawnością fizyczną badanych osób.

Oceny sprawności fizycznej dokonano także w zależności od wielkości BMI. Średnia wielkość BMI była podstawą podziału badanych na dwie grupy: o mniejszej masywności ciała (BMI poniżej 21; -0,25 w skali „Z") i o większej masywności ciała (BMI powyżej 21). Różnice między tymi grupami oceniano przy użyciu testu t-Studenta dla prób niezależnych w przypadku cech o rozkładzie normalnym. W przypadku cech o rozkładzie skośnym ocena różnic została dokonana przy zastosowaniu testu U-Manna-Whitneya (Łomnicki 2003). Normalność rozkładu zbadano testem Kołmogorowa-Smirnowa, a jednorodność wariancji testem Levene'a. Tylko w przypadku gibkości kręgosłupa stwierdzono niejednorodność wariancji i posłużono się nieparametrycznym testem U-Manna-Whitneya.

\section{Analiza wyników}

Zastosowanie analizy głównych składowych pozwoliło na wyodrębnienie pięciu czynników, które w zależności od skorelowanych z nimi charakterystyk społeczno-bytowych noszą odpowiednie nazwy: F1 „wielkość rodziny”, F2 - „warunki społeczno-bytowe”, F3 - „poziom stresu”, F4 - „tryb życia” oraz F5 - „dym tytoniowy”. Czynniki te wyjaśniają zmienność wszystkich analizowanych charakterystyk rodzinnych w $67 \%$ (Tab. 1). 


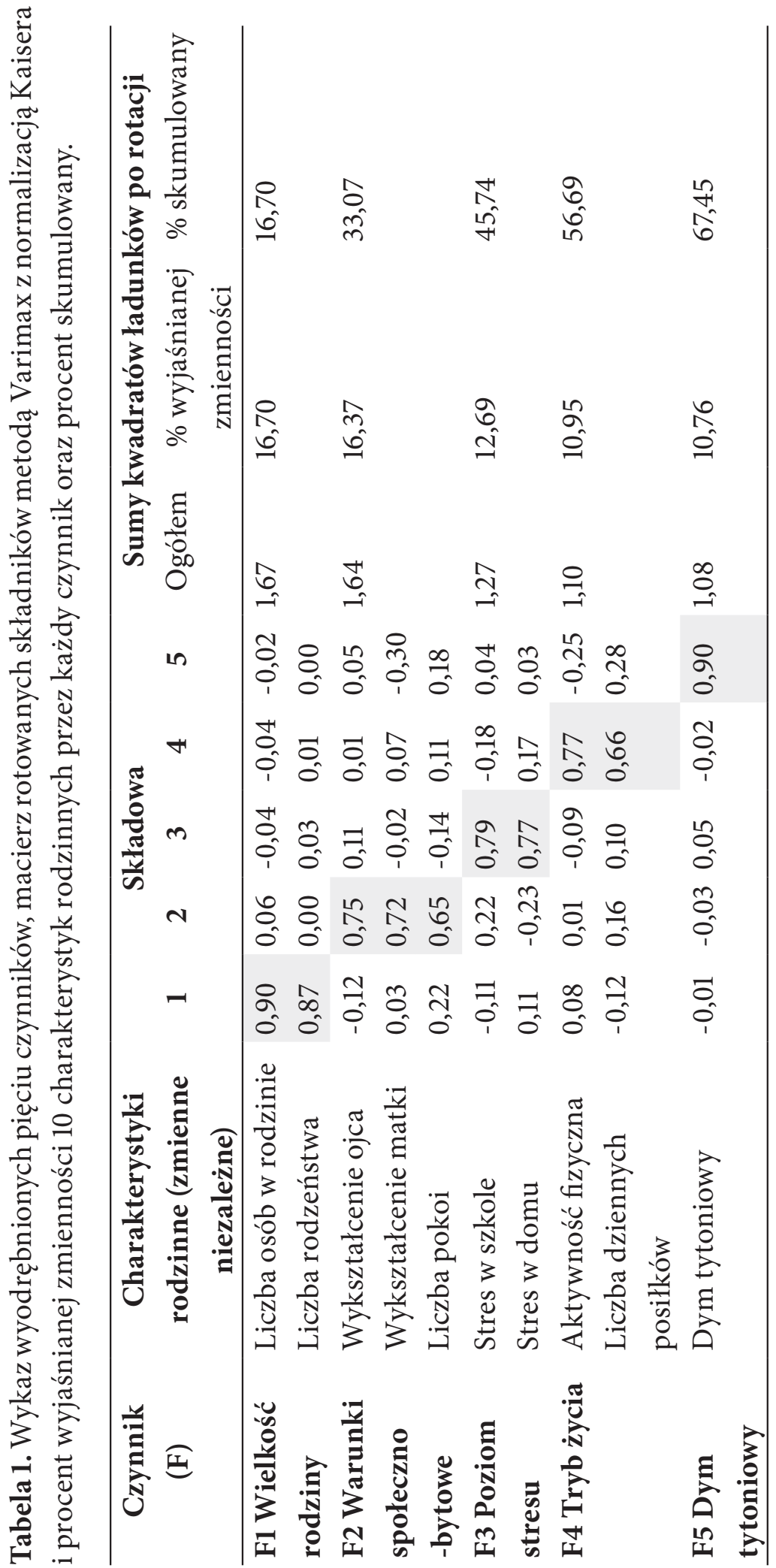


Wyniki analizy regresji liniowej w wersji krokowej (Tab. 2) dowodzą, że siła statyczna ręki dominującej, zwinność w biegu, liczba siadów z leżenia, siła eksplozywna kończyn dolnych oraz szybkość reakcji wykazują istotny statystycznie związek ze zmiennymi niezależnymi. Nie zanotowano związku między gibkością kręgosłupa, a pięcioma wyodrębnionymi czynnikami, dlatego dane te nie znalazły sie w Tabeli 2.

Widoczne jest, że siła statyczna ręki dominującej wykazała ujemną korelację z czynnikami „poziom stresu” i „dym tytoniowy”, co wskazuje, że w warunkach stresowych, przy paleniu tytoniu i/lub narażeniu na dym palaczy badana młodzież osiąga gorsze rezultaty. Wyniki próby na zwinność w biegu wykazały istotny związek z dwoma czynnikami: „wielkość rodziny” i „poziom stresu”. Im w większej rodzinie młodzież wychowywała się i im wyższy poziom stresu badani deklarowali, tym zwinność mierzona średnim czasem przebiegu trzech ósemek była niższa. „Tryb życia” i „dym tytoniowy” to dwa czynniki mające istotny wpływ na liczbę siadów z leżnia. Przy bardziej aktywnym trybie życia, większej liczbie posiłków i braku narażenia na dym tytoniowy badana młodzież wykony wała większą liczbę siadów $\mathrm{z}$ leżenia w ciągu 30 sekund w porównaniu do młodzieży mniej aktywnej fizycznie, spożywającej mniej niż 3 posiłki dziennie oraz narażonej na dym tytoniowy. Siła eksplozywna kończyn dolnych, mierzona wyskokiem dosiężnym, wykazała negatywny związek z narażeniem na dym tytoniowy, podobnie jak szybkość reakcji wykazała negatywny związek z czynnikiem „tryb życia”. Oznacza to, że siła eksplozywna była większa u młodzieży niepalącej oraz szybkość reakcji tejże młodzieży była krótsza, gdy deklarowali oni większą aktywność fizyczną i większą liczbę dziennych posiłków.

Jedynie gibkość kręgosłupa badanej młodzieży nie wykazywała związku z żadnym z wyodrębnionych pięciu czynników charakteryzujących warunki bytowe i tryb życia. 
Tabela 2. Czynniki wykazujące istotny statystycznie związek z cechami sprawnościowymi u młodzieży warszawskiej.

\begin{tabular}{|c|c|c|c|c|c|}
\hline $\begin{array}{l}\text { Cechy sprawnoś- } \\
\text { ciowe (zmienne } \\
\text { zależne) }\end{array}$ & $\begin{array}{l}\text { Czynnik i kierunek } \\
\text { jego związku ze } \\
\text { zmienną zależną }\end{array}$ & $\begin{array}{l}\text { Współ. Beta } \\
\text { (standaryzo- } \\
\text { wany) }\end{array}$ & $\mathbf{T}$ & $P$ & $\begin{array}{c}\text { \% wyjaś- } \\
\text { nianej } \\
\text { zmienności } \\
\left(\mathrm{R} 2^{\star} 100\right)\end{array}$ \\
\hline Siła statyczna & F3 - poziom stresu & $-0,211$ & $-2,907$ & 0,004 & $4,0 \%$ \\
\hline ręki & F5 - dym tytoniowy & $-0,218$ & $-3,007$ & 0,003 & $4,2 \%$ \\
\hline Zwinność & F1- wielkość & 0,170 & 2,287 & 0,023 & $2,3 \%$ \\
\hline w biegu po & rodziny & 0,161 & 2,174 & 0,031 & $2,1 \%$ \\
\hline ósemce & F3 - poziom stresu & & & & \\
\hline Liczba siadów & F4 - tryb życia & 0,188 & 2,552 & 0,012 & $3,0 \%$ \\
\hline z pozycji leżącej & F5 - dym tytoniowy & $-0,177$ & $-2,399$ & 0,018 & $2,6 \%$ \\
\hline $\begin{array}{l}\text { Siła eksplo- } \\
\text { zywna kończyn } \\
\text { dolnych (wyskok }\end{array}$ & F5 - dym tytoniowy & $-0,187$ & $-2,507$ & 0,013 & $2,9 \%$ \\
\hline Sargenta) & & & & & \\
\hline Szybkość reakcji & F4 - tryb życia & $-0,151$ & $-2,006$ & 0,046 & $1,7 \%$ \\
\hline
\end{tabular}

Ocena wyników prób sprawnościowych między młodzieżą o większej i mniejszej masywności budowy (BMI) wykazała różnice istotne statystycznie w przypadku trzech testów (Tab. 3 i 4). Z e względu na zastosowanie różnych testów wyniki przedstawiono w dwóch oddzielnych tabelach (test t-Studenta dla prób niezależnych w przypadku cech o rozkładzie normalnym i test U-Manna-Whitneya w przypadku cechy o rozkładzie skośnym).

U osobników o mniejszych wielkościach BMI obserwuje się mniejszą siłę mięśniową, ale większą gibkość kręgosłupa i krótszy czas w biegu po ósemce niż u osobników charakteryzujących się większymi wielkościami BMI. 


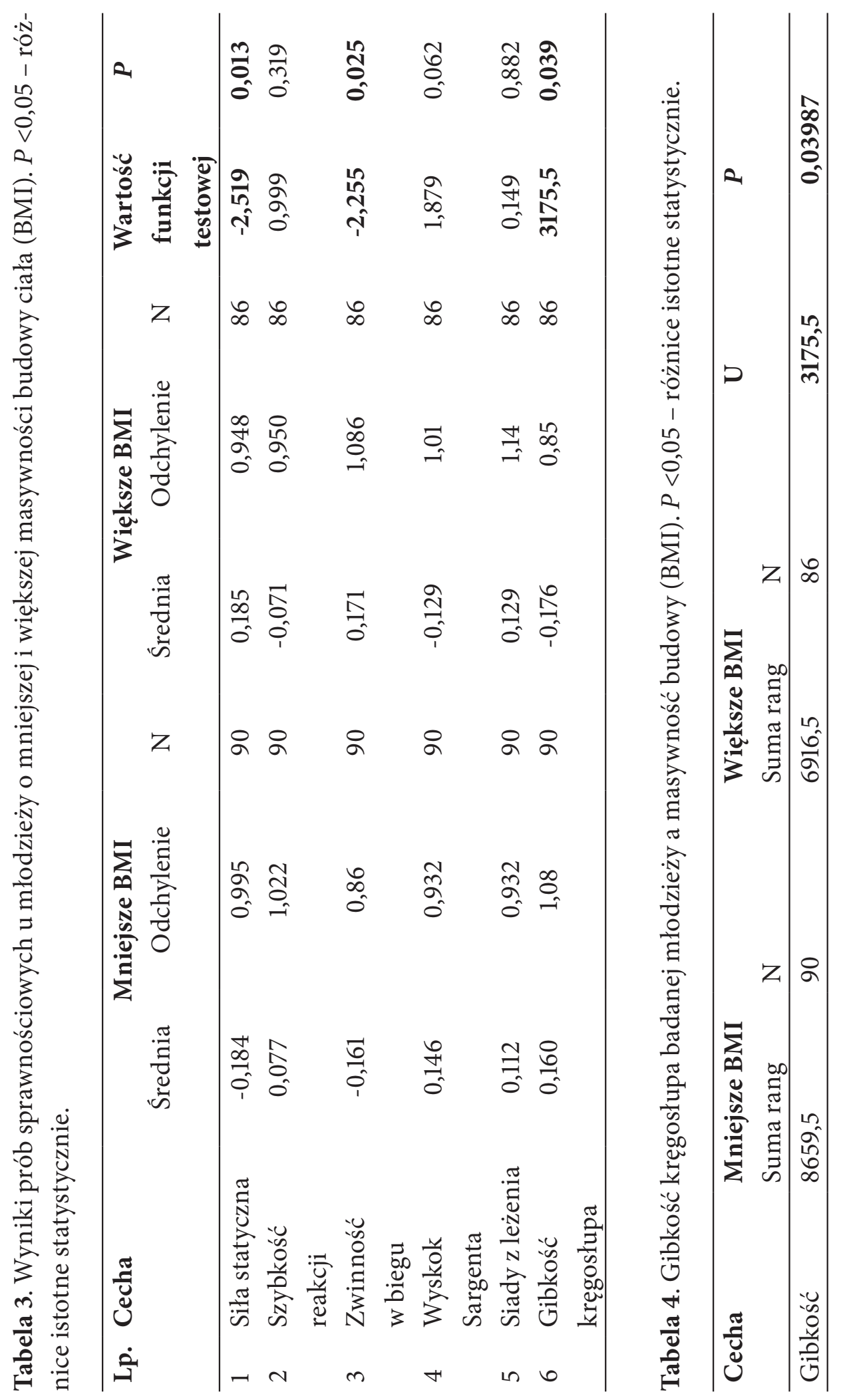




\section{Dyskusja}

Wyniki niniejszej pracy wykazały, że zmienne niezależne, pogrupowane w czynniki, takie jak: wielkość rodziny, poziom stresu, tryb życia i dym tytoniowy w niewielkim, ale jednak istotnym statystycznie stopniu wyjaśniają zróżnicowanie zmiennych zależnych, czyli pięciu badanych cech sprawnościowych. Jedynie jeden $\mathrm{z}$ wyodrębnionych czynników „warunki społeczno-bytowe” (wykształcenie ojca i matki oraz wielkość mieszkania) nie wykazał żadnego związku z przeprowadzonymi próbami sprawności fizycznej badanych osób.

Wśród obserwowanej młodzieży, w przypadku trzech cech (siła statyczna ręki dominującej, wytrzymałość oraz siła eksplozywna kończyn dolnych), dym tytoniowy obniżał uzyskane wyniki. Podobnie deklarowany przez gimnazjalistów wyższy poziom stresu, zarówno w domu, jak i w szkole wpływał na gorsze wyniki uzyskiwane w teście siły statycznej ręki dominującej (mniej kg) oraz w teście zwinności biegu po ósemce (gorszy czas). Czynnik nazwany „trybem życia”, a określany przez poziom aktywności fizycznej oraz liczbę dziennych posiłków gimnazjalistów, związany był pozytywnie z wynikami siły statycznej ręki dominującej oraz z liczbą siadów z pozycji leżącej. Także czynnik „wielkość rodziny” wykazywał negatywny związek z czasem biegu po ósemce.

$\mathrm{Z}$ danych dostępnych w literaturze wynika, że warunki bytowe, $\mathrm{w}$ tym liczba członków rodziny korelują z poziomem sprawności fizycznej. Wśród młodzieży, u której zanotowano większą liczbę osób w rodzinie obserwowano niższy poziom sprawności fizycznej (Orlicz 1996: 3-10, Kilani et al. 2013: 510-519, Frederick et al. 2014: 1338-1342, Mangerud et al. 2014: 2). Jednakże w badaniach Miązek et al. (2005: 424-428) liczba rodzeństwa nie miała wpływu na sprawność fizyczną, przy czym w testach sprawnościowych najgorzej wypadali jedynacy (Mandziuk 2011: 127-132).

Wśród modyfikatorów rozwoju wymienia się także wpływ palenia papierosów na rozwój dzieci i młodzieży, a także na poziom sprawności fizycznej (Moszczyński 2003: 3-7, Milnerowicz, Śliwińska-Mossoń 2007: 660-663, Woźniacka et al. 2012: 202-206, Eleftheriou 2013: 
17-26). Wśród badanych osób trzy oceniane cechy sprawnościowe wykazywały związek z paleniem papierosów. Mimo, że młodzież deklarowała, że nie pali papierosów, to jednak wdychanie substancji $\mathrm{z}$ dymu papierosowego np. jeśli palą rodzice (tzw. bierne palenie) wykazuje istotną statystycznie, ujemną korelację ze sprawnością fizyczną.

Mimo, że w obecnym opracowaniu, a także w innych publikacjach autorów (Denisiuk 1968), nie znaleziono zależności między warunkami społeczno-bytowymi, ocenianymi głównie wykształceniem rodziców, a sprawnością w wykonywanych próbach to inni autorzy znaleźli współzależność między stopniem wykształcenia rodziców, a sprawnością fizyczną dzieci. Obserwowano, że lepiej wykształceni rodzice posiadali sprawniejsze dzieci (Przewęda 1985, Zadarko-Domaradzka et al. 2006: 206-212, Tandon et al. 2012: 9-88). Podobne wyniki uzyskano u dziewcząt z USA, pochodzących z rodzin o niższym statusie społeczno-ekonomicznym (co ma również związek z poziomem wykształcenia rodziców), które cechowały się niższą sprawnością fizyczną (Bohr et al. 2013: 542-547).

Jak wspomniano na początku dyskusji, wyniki niniejszej pracy wskazywały na związek poziomu stresu, zarówno w domu jak i w szkole, na badane cechy sprawnościowe. Nie wszyscy autorzy znaleźli podobne zależności (Nguyen-Michel et al. 2006: 179-188). Wskazywano również, że zbyt duży wskaźnik BMI sam w sobie może być powodem stresu (Robinson 2014: 1380-1386).

Podział badanych w niniejszej pracy na osoby o większym i mniejszym wskaźniku BMI i wpływ tej cechy na sprawność fizyczną wykazał, że młodzież o mniejszych wielkościach BMI charakteryzuje się mniejszą siłą mięśniową, ale większą gibkością kręgosłupa i lepszą zwinnością niż chłopcy i dziewczęta o większych wielkościach BMI.

Większy wskaźnik BMI może być spowodowany większą otyłością, ale również większym rozwojem masy mięśniowej, szczególnie u młodzieży, która jest aktywna fizycznie. W przypadku zwiększonej otyłości, młody organizm narażony jest na upośledzenie układu ruchu, w tym nadmierne obciążenia kręgosłupa oraz stawów (Januszewicz, Sygit 2003: 421-425, Szymura, Cempla 2003: 271-276, Gill, Hung 2012: 625-630), co również wiąże się z niższą wydolnością organizmu 
(D'Hondt et al. 2008: 72-75, Huang, Malina 2010: 404-411, Popławska et al. 2011: 22-26). Choć nadwaga i otyłość mogą powodować wzrost siły mięśniowej (Malina et al. 1995: 221-231, Ignasiak et al. 2000: 65-67, Maciaszek 2000, Barańska et al. 2012: 337-341), to niniejsze badania nie potwierdzają takiej zależności. Poświadczają to także wyniki badań przedstawione przez innych autorów, którzy wskazują, że osoby o większym BMI wypadają gorzej w pewnych aspektach motoryczności (Ignasiak et al. 2000: 65-67, Barańska, Gajewska 2009: 337-341, Alberga et al. 2013: 103-109). Inne prace wskazują natomiast na brak różnic istotnych statystycznie między wynikami testów motorycznych między młodzieżą ze zróżnicowaną masywnością budowy (Zieniewicz et al. 1999, Deforche et al. 2003: 434-441).

Charakterystyki warunków bytowych i trybu życia, które zostały wzięte pod uwagę, nie wpływają znacząco na poziom wykonywanych testów sprawnościowych, a procent wyjaśnianej zmienności jest niski. Świadczy to, że istnieją inne czynniki, które te cechy determinują. Ostatnie doniesienia dotyczące wpływu niektórych polimorfizmów genów, np. ACE (Maffulli et al. 2013: 173-189), ACTN3 (Fedotovskaya et al. 2012:15-25) czy PPARA (Ahmetov et al. 2012: 151-159) na osiąganie lepszych wyników sportowych sugerują, że sprawność motoryczna kształtowana jest przez szereg czynników. Wielu autorów podkreśla, że poza uwarunkowaniami genetycznym, w przypadku wyników sportowych ważna jest także motywacja, kontakt z rówieśnikami, wpływ opiekuna lub nauczyciela prowadzącego zajęcia z wychowania fizycznego (Skonieczka 2011: 95-100, Ridder et al. 2014: 15-25).

Podsumowując niniejsze badania można stwierdzić, iż sprawność fizyczna młodzieży warszawskiej uwarunkowana jest przez niektóre czynniki społeczno bytowe oraz jest zależna od masywności budowy ciała. Większa sprawność fizyczna charakteryzuje młodzież pochodzącą z mniejszych rodzin i mniej narażoną na stres i używki. Natomiast młodzież cechująca się większym wskaźnikiem BMI wykazywała gorsze wyniki w zastosowanych testach sprawnościowych, z wyjątkiem siły statycznej ręki dominującej.

Ze względu na stale zmieniające się warunki socjo-ekonomiczne niezwykle ważnym elementem jest obserwacja dobrostanu 
biologicznego dzieci i młodzieży, dlatego też tego typu analizy są niezbędnym elementem badań nad biologią człowieka.

\section{Wnioski}

1. Spośród badanych prób sprawnościowych jedynie gibkość kręgosłupa nie wykazywała związku z zmiennymi niezależnymi:

a) Siła statyczna ręki dominującej wykazywała ujemną korelację z czynnikami „poziom stresu” i „dym tytoniowy”;

b) Zwinność w biegu po ósemce przejawiała istotny związek z czynnikami „wielkość rodziny” i „poziom stresu”;

c) Liczba siadów z leżenia była zależna od czynników „tryb życia” i „dym tytoniowy”;

d) Siła eksplozywna kończyn dolnych wykazywała ujemną korelację z czynnikiem „tryb życia”.

2. Wyniki analizy prób sprawnościowych u młodzieży cechującej się mniejszą masywnością budowy w stosunku do osób o większej masywności budowy, wykazały różnice istotne statystycznie i wskazywały na:

a) Mniejszą siłę mięśniową;

b) Większą gibkość kręgosłupa;

c) Krótszy czas biegu po ósemce.

\section{Bibliografia}

Ahmetov I., Maciejewska-Karłowska A., Buryta M., Grenda A., Wiażewicz A., 2012, Polimorfizm genu PPARA u polskich sportowców z grupy dyscyplin siłowych, Zeszyty Naukowe Uniwerstyetu Szczecińskiego, 28, 151-159.

Alberga A.S., Farnesi B.C., Lafleche A., Legault L., Komorowski J., 2013, The effects of resistance exercise training on body composition and strength in obese prepubertal children, The Physician and Sportsmedicine, 41, 103-109.

Barańska E., Gajewska E., 2009, Ocena sprawności motorycznej występującej u dzieci z nadwagą i otyłościa, Nowiny Lekarskie, 78, 182-185. 
Barańska E., Gajewska E., Sobieska M., 2012, Otyłość i wynikające z niej problemy narzadu ruchu a sprawność motoryczna dziewczat $i$ chłopców z nadwaga i otyłością prostą, Nowiny Lekarskie, 81, 337-341.

Bohr A.D., Brown D.D., Laurson K.R., Smith P.J., Bass R.W., 2013, Relationship between socioeconomic status and physical fitness in junior high school students, Journal of School Health, 83, 542-547.

Chabros E., Charzewska J., Wajszczyk B., Chwojnowska Z., 2011, Częstość występowania niedoborowej masy ciała u młodzieży warszawskiej $w$ wieku pokwitania w ostatnich 3 dekadach, Problemy Higieny i Epidemiologii, 91, 99-102.

Deforche B., Lefevre J., De Bourdeaudhuij I., Hills A.P., Duquet W., Bouckaert J., 2003, Physical fitness and physical activity in obese and nonobese Flemish youth, Obesity research, 11: 434-441.

Denisiuk L., 1968, Dynamika Rozwoju Fizycznego i Sprawności Fizycznej Dzieci Klas I-IV Szkół Podstawowych, wyd. Roczniki Naukowe AWF, Warszawa.

D'Hondt E., Deforche B., De Bourdeaudhuij I., Lenoir M., 2008, Childhood obesity affects fine motor skill performance under different postural constraints, Neuroscience Letters, 440, 72-75.

Dobosz J., 2012, Tabele Punktacyjne Testów Eurofit Międzynarodowego i Coopera dla Uczniów i Uczennic Szkół Podstawowych, wyd. Akademia Wychowania Fizycznego w Warszawie, Warszawa.

Eleftheriou K.I., Rawal J.S., James L.E., Payne J.R., Loosemore M., Pennell D.J., World M., Drenos F., Haddad F.S., Humphries S.E., Sanders J., Montgomery H.E., 2013, Bone structure and geometry in young men: the influence of smoking, alcohol intake and physical activity, Bone, 52, 17-26.

Fedotovskaya O., Cięszczyk P., Leońska-Duniec A., Buryta M., Grenda A., Wiażewicz A., 2012, Rola i znaczenie polimorfizmu R577X w genie ACTN3 u polskich wioślarzy o wysokich kwalifikacjach, Zeszyty Naukowe Uniwersytetu Szczecińskiego, 28, 15-25.

Frederick C.B., Snellman K., Putnam R.D., 2014, Increasing socioeconomic disparities in adolescent obesity, Proceedings of the National Academy of Sciences, 111, 1338-1342. 
Garatachea N., Lucia A., 2013, Genes, physical fitness and ageing, Ageing Research Reviews, 12, 90-102.

Gill S.V., Hung Y.C., 2012, Influence of weight classification on children stepping over obstacles, American Journal of Physical Medicine \& Rehabilitation, 91, 625-630.

Gołąb S., Sobiecki J., Matusik S., 2005, Uwarunkowania sprawności i wydolności fizycznej mężczyzn z populacji krakowskiej, Annales Universitatis Mariae Curie-Skłodowska Lublin - Polonia, LX, 66-70.

Gulías-González R., Martínez-Vizcaíno V., García-Prieto J.C., Díez-Fernández A., Olivas-Bravo A., Sánchez-López M., 2013, Excess of weight, but not underweight, is associated with poor physical fitness in children and adolescents from Castilla-La Mancha, Spain, European Journal of Pediatrics, 173, 727-735.

Huang Y.C., Malina R.M., 2002, Physical activity and health-related physical fitness in Taiwanese adolescents, Journal of Physiological Anthropology and Applied Human Science, 21, 11-19.

Huang Y.C., Malina R.M., 2007, BMI and health-related physical fitness in Taiwanese youth 9-18 years, Medicine \& Science in Sports \& Exercise, 39, 701-708.

Huang Y.C., Malina R.M., 2010, Body mass index and individual physical fitness tests in Taiwanese youth ages 9-18 years, International Journal of Pediatric Obesity, 5, 404-411.

Ignasiak Z., Sławińska T., Januszewski A., 2000, Otłuszczenie ciała a sprawność motoryczna młodzieży w okresie pokwitania, Nowa Medycyna, 7, 65-67.

Januszewicz P., Sygit M., 2003, Otyłość u dzieci i młodzieży - epidemia XXI wieku?, Przegląd medyczny Uniwersytetu Rzeszowskiego, 4, 421-425.

Jodkowska M., Tabak I., Oblacińska A., 2007, Aktywność fizyczna i zachowania sedenteryjne gimnazjalistów z nadwaga i otyłościa $w$ Polsce w 2005 r., Problemy Higieny i Epidemiologii, 2, 149-156.

Kilani H., Al-Hazzaa H., Waly M.I., Musaiger A., 2013, Lifestyle Habits: Diet, physical activity and sleep duration among Omani adolescents, Sultan Qaboos University Medical Journal, 13, 510-519. 
Łomnicki A., 2003, Wprowadzenie do Statystyki dla Przyrodników, wyd. Państwowe Wydawnictwo Naukowe, Warszawa.

Maciaszek J., 2000, Związki Czynników Sprawności Fizycznej, Związanych ze Zdrowiem, Badanych Testem EUROFIT - z wysokościa, masa oraz otłuszczeniem ciała u dzieci poznańskich w wieku 10-14 lat, wyd. Roczniki naukowe AWF, Poznań.

Maffulli N., Margiotti K., Longo U.G., Loppini M., Fazio V.M., Denaro V., 2013, The genetics of sports injuries and athletic performance, Muscle, Ligaments and Tendons Journal, 11, 173-189.

Malina R.M., Beunen G.P., Classens A.L., Lefevre J., Vanden Eynde B.V., Renson R., Vanreusel B., Simons J., 1995, Fatness and physical fitness of girls 7 to 17 years, Obesity Research, 3, 221-231.

Malinowski A., 1980, Antropologia Fizyczna, wyd. Państwowe Wydawnictwo Naukowe, Warszawa.

Malinowski A., Bożiłow W., 1997, Podstawy Antropometrii, wyd. Państwowe Wydawnictwo Naukowe, Warszawa-Łódź.

Malinowski A., Strzałko J., 1985, Antropologia, wyd. Państwowe Wydawnictwo Naukowe, Warszawa-Poznań.

Malinowski A., Wolański N., 1988, Metody Badań w Biologii Człowieka, Wybór Metod Antropologicznych, wyd. Państwowe Wydawnictwo Naukowe, Warszawa.

Mandziuk M., 2011, Ocena Sprawności Fizycznej Uczniów Klas IV-VI ze Szkół Podstawowych w Białej Podlaskiej z Uwzględnieniem Liczby ich Rodzeństwa, Roczniki Naukowe Wyższej Szkoły Wychowania Fizycznego i Turystyki, 7, 127-132.

Mangerud W.L., Bjerkeset O., Lydersen S., Indredavik M.S., 2014, Physical activity in adolescents with psychiatric disorders and in the general population, Child and Adolescent Psychiatry and Mental Health, 8, 2.

Martin R., Saller K., 1957, Lehrbuch der Anthropologie, wyd. Fischer Verlag, Stuttgart.

Miązek U., Szyndera M., Żiszka-Salamon, 2005, Socjalne uwarunkowania aktywności fizycznej w stylu życia żeńskiej młodzieży studiujacej w Krakowie, Annales Univeritatis Mariae Curie-Skłodowska Lublin - Polonia, LX, 424-428. 
Milnerowicz H., Śliwińska-Mossoń M., 2007, Wplyw palenia papierosów na wydolność fizyczna u młodych mężczyzn (część II), Przegląd Lekarski, 64, 660-663.

Moszczyński P., 2003, Choroby tytoniozależne (Przegląd piśmiennictwa i badania własne), Lider, 14, 3-7.

Nguyen-Michel S.T., Unger J.B., Hamilton J., Sprujti-Metz D., 2006, Association between physical activity and perceived stress/hassles in college students, Stress and Health, 22, 179-188.

Orlicz B., 1996, Społeczne uwarunkowania sprawności fizycznej dziewczat polskich, Wychowanie fizyczne i sport, XL, 3-10.

Osiński W., 2003, Sprawność, Antropomotoryka, wyd. Akademia Wychowania Fizycznego w Poznaniu, Poznań.

Pälve K.S., Pahkala K., Magnussen C.G., Koivistoinen T., Juonala M., Kähönen M., Lehtimäki T., Rönnemaa T., Viikari J.S., Raitakari O.T., 2014, Association of physical activity in childhood and early adulthood with carotid artery elasticity 21 years later: the cardiovascular risk in young Finns study, Journal of the American Heart Association 3:e000594, doi: 10.1161/JAHA.113.000594.

Popławska H., Dmitruk A., Hołub W., Wilczewski A., 2011, Niedowaga i nadwaga a sprawność fizyczna dziewcząt ze wschodniej Polski, Zdrowie Publiczne, 121, 22-26.

Przewęda R., 1985, Uwarunkowania Poziomu Sprawności Fizycznej Polskiej Młodzieży Szkolnej, wyd. Akademia Wychowania Fizycznego w Warszawie, Warszawa.

Przewęda R., Dobosz J., 2003, Kondycja fizyczna polskiej młodzieży, Studia i Monografie AWF, 98, 2-10.

Radovanović S., Kocić S., Gajović G., Radević S., Milosavljević M., Nićiforović J., 2014, The impact of body weight on aerobic capacity, Medicinski glasnik, 11, 204-209.

Rauner A., Mess F., Woll A., 2013, The relationship between physical activity, physical fitness and overweight in adolescents: a systematic review of studies published in or after 2000, Pediatrics, 13, 1-9.

Ridder M.A., Visscher T.L., Hirasing R.A., Seidell J.C., Renders C.M., 2014, Dutch teachers and parents about overweight prevention in pre-vocational schools, Health Promotion International, 29, 15-25. 
Robinson E., Christiansen P., 2014, The changing face of obesity: exposure to and acceptance of obesity, Obesity (Silver Spring), 22, $1380-1386$.

Skonieczka M., 2011, Rodzinne uwarunkowania aktywności fizycznej w przeglądzie piśmiennictwa, Rocznik Naukowy, 21, 95-100.

Szymura J., Cempla J., 2003, Wydolność fizyczna 9-10 letnich dziewcząt o różnym poziomie otłuszczenia, Nowiny lekarskie, 72, 271-276.

Tandon P.S., Zhou C., Sallis J.F., Cain K.L., Frank L.D., Saelens B.E., 2012, Home environment relationships with children's physical activity, sedentary time, and screen time by socioeconomic status, International Journal of Behavioral Nutrition and Physical Activity, 9:88, doi: 10.1186/1479-5868:9-88.

Wojtyła A., Biliński P., Bojar I., Wojtyła K., 2011, Aktywność fizyczna młodzieży gimnazjalnej $w$ Polsce, Problemy Higieny i Epidemiologii, 2, 335-342.

Wolański N., 2012, Rozwój Biologiczny Człowieka, wyd. Wydawnictwo Naukowe PWN Warszawa.

Wolański N., Parízková J., 1976, Sprawność Fizyczna a Rozwój Człowieka, wyd. Sport i Turystyka, Warszawa.

Woźniacka A., Woźniacka-Węgierska M., Józefowicz O., Sysa-Jędrzejowska A., 2012, Medyczne i prawne aspekty palenia tytoniu, Polski Merkuliusz Lekarski, XXXII, 202-206.

Zadarko-Domaradzka M., Tlałka E., Sobolewski M., 2006, Społeczno kulturowe uwarunkowania aktywności ruchowej młodzieży gimnazjalnej Sanoka, Przegląd Naukowy Kultury Fizycznej Uniwersytetu Rzeszowskiego, 2, 206-212.

Zieniewicz A., Skład M., Popławska H., Saczuk J., 1999, Poziom Wybranych Cech Somatycznych oraz Motoryka Dziewczat o Zróżnicowanym Stopniu Ottuszczenia, wyd. Instytut Wychowania Fizycznego i Sportu, Biała Podlaska. 